\title{
Reintroducing plant coverage in a tropical wetland contaminated with oil and sulfate: rhizosphere effects on Desulfovibrio populations
}

\author{
Antonio Trujillo-Narcía ${ }^{1}$, María del Carmen Rivera-Cruz ${ }^{2 *}$, Eduardo Antonio Trujillo-Rivera ${ }^{3}$ \\ \& Antonio Roldán Garrigos ${ }^{4}$ \\ 1. Cuerpo Académico Energía y Medioambiente. Programa Educativo QFB. Universidad Popular de la Chontalpa. \\ Carretera Cárdenas-Huimanguillo km 2, H. Cárdenas, Tabasco, México. CP 86500; atrujillonarcia@gmail.com \\ 2. Colegio de Postgraduados Campus Tabasco. Laboratorio de Microbiología Agrícola y Ambiental. Periférico Carlos A. \\ Molina s/n km 3.5, H. Cárdenas, Tabasco, México; mariari@colpos.mx \\ 3. Science \& Engineering Hall, Suite 8390, The George Washington University, 800 22nd St NW, Washington, DC, \\ USA, 20052; eduardotrujillo@gwu.edu \\ 4. CSIC. Centro de Edafología y Biología Aplicada del Segura, Depto. de Conservación del Suelo y Agua. Campus \\ Universitario de Espinardo. Murcia, España. E-30100; aroldan@cebas.csic.es
}

Received 27-II-2018. C Corrected 08-III-2018. Accepted 06-IV-2018.

\begin{abstract}
The Mexican tropical wetland is a coastal system with capacity to support the contamination derived from the extractive industry and the transformation of crude oil, due to its high plant biodiversity and the presence of rhizospheric reducing sulphate bacteria from plants tolerant to crude oil. A field experiment was carried out for nine months to evaluate the adaptation of aquatic plants Leersia hexandra grass and Eleocharis palustris spikerush reintroduced in a wetland contaminated with 75560 to $118789 \mathrm{mg} \mathrm{kg}^{-1}$ of weathered petroleum and also with sulfate, derived from oil and gas pipeline leaks, and gaseous emissions. The effect of the weathered oil and sulfate on the dry matter production and the population density of the bacterium Desulfovibrio spp, isolated from the rhizosphere and soil of both plants, were evaluated. The means of the variables had statistical differences $(\mathrm{p}<0.05)$. Weathered oil inhibited dry matter production of L. hexandra but not E. palustris; the effect of petroleum on Desulfovibrio density was very significant negative in the rhizosphere and in the soil of both plants. Sulfate reduced the dry matter of grass. The exposure of Desulfovibrio to sulfate significantly reduced its density in rhizosphere and soil $(\mathrm{p}<0.01)$. We recommend the use of E. palustris for the decontamination of flooded soils contaminated with weathered oil and sulfate. Rev. Biol. Trop. 66(2): 908-917. Epub 2018 June 01.
\end{abstract}

Key words: bacteria; Gleysol; Eleocharis; Leersia; weathered petroleum.

The extraction and transportation of crude oil is an environmental problem for the ecosystem (Muratova, Dmitrieva, Panchenko, \& Turkovskaya, 2008) due to accidental spilling and subsequent permanence of oil in soils. In the Mexican humid tropics there are farms where oil has been spilled and then remains in the soil (Rivera-Cruz, Trujillo-Narcía, TrujilloRivera, Arias-Trinidad, \& Mendoza-López, 2016). These farms make use of forage crops adapted to wetlands, where there is a predominance of stationary flooding, low permeability of soils and shallow water cover (Comisión Nacional para el Conocimiento y Uso de la Biodiversidad [CONABIO], 2009). The initial spill of crude oil in the soil inhibits native life, but when it remains for a long period time it is colonized by organisms which are tolerant to hydrocarbons. In this regard Merkl, SchultzeKraft \& Infante (2005) and Basumatary, Bordoloi \& Sarma (2012) demonstrated that tropical grass Brachiaria brizantha, and sedge Cyperus brevifolius are resistant to petroleum-polluted soils. The tropical grasses Paspalum virgatum 
and Echinochloa polystachya, prevalent in contaminated wetlands, possessing rhizospheres colonized by beneficial bacteria (Rivera-Cruz, 2011). Plants and bacteria resistant to contamination are the basis of biological succession for the restoration of degraded lands in these ecosystems. Adaptation of grasses and sedges to stress conditions is due to two reasons. First, when the plant is exposed to a contaminant it actives its antioxidant enzyme system and molecular defense for its anatomical and physiological adaptation (Martí et al., 2009). Second, the fibrous structure, extensive root systems, root exudates and microbial density in the rhizosphere use available organic and inorganic molecules as sources of carbon and energy (Basumatary, Bordoloi, \& Sarma, 2012; Rivera-Cruz, Maldonado-Chávez, \& TrujilloNarcía, 2012). In barium sulfate mines and soils contaminated with oil, and also acidophilus soils which predominate in farms in the humid tropics, there are sulfate-reducing bacteria (SRB) (Fernández, Rojas, \& Roldán, 2006; Babu, Subramanyam, Sreenivasulu, \& Paramageetham, 2014). The SRB are a unique physiological group of heterotrophic prokaryotes because they have the capability of using sulfate as the final electron acceptor in respiration. SRB are anaerobes which are characterized by their ability to perform dissimilatory sulfate reduction with the simultaneous oxidation of the organic substrates (Hansen, 1994). The SRB use electrons as donors for the reduction of hydrogen sulfate, ethanol, acetate, lactate, propionate, pyruvate (Liamleam \& Annachhatre, 2007) and hydrocarbons (Madigan, Martinko, Bender, Buckley, \& Sthal, 2015). An example of SRB is the subgroup Desulfovibrio which is heterotrophic and capable of using the $\mathrm{SO}_{4}^{-2}$ or sulfur oxyanions as electron acceptors in the process of sulfate reductive assimilation to $\mathrm{H}_{2} \mathrm{~S}$ (Hurst, 2002). The reduction to $\mathrm{H}_{2} \mathrm{~S}$ by the sulfate reductive assimilation pathway is a natural in situ process under anaerobic conditions and is based on the following two fundamental reasons. Firstly, SRB have the capacity to reduce sulfate to sulfide, which then reacts with certain metals to form insoluble precipitates. Secondly, the system acidity is reduced by their own action of sulfate reduction and by the carbon metabolism of the bacteria (García, Moreno, Ballester, Blázquez, \& González, 2001). Desulfovibrio can inhabit soils contaminated with petroleum oil (Fernández, Rojas, \& Roldán, 2006) but it also colonizes the rhizosphere of hydrophilic plants. The rhizosphere is critical for Desulfovibrio populations because it is the space where the roots stabilize organic and inorganic molecules by a radical adhesion process and organic and inorganic exudates (Dzantor, 2007). These exudates provide sufficient carbon and energy to support a large number of microbes in the rhizosphere (Erickson, Davis, \& Narayanan, 1995). This plant-induced enhancement of the microbial population is called the rhizosphere effect (Atlas \& Bartha, 2002). The rhizosphere of the grasses E. polystachya and C. brevifolius have shown a potential to be colonized by microorganisms and to degrade petroleum hydrocarbons (Rivera-Cruz \& Trujillo-Narcía, 2004; Basumatary, Bordoloi, \& Sarma, 2012; Rivera-Cruz et al., 2016). L. hexandra and E. palustris are potentially interesting species for the restablishment of plant cover in oil contaminated soils. As both are mostly vegetatively propagated species, the best method for its establishment in these environments is planting rhizomes. L. hexandra has a fibrous and stoloniferous root system and creeping growth. $E$. palustris has taproots with tiller growth. Both root systems can control the spread of petroleum hydrocarbons in soils. The overall aim of this research was to evaluate the suitability of L. hexandra and E. palustris for recovering plant cover in a tropical wetland contaminated with oil, as well as to assess the effect of introduced vegetation on Desulfovibrio populations.

\section{MATERIALS AND METHODS}

Study area and environmental conditions: Comprises $26254 \mathrm{~m}^{2}$ at La Venta, Tabasco, located in Southeast Mexico (UTM 389515 and 1998987) at $3 \mathrm{~m}$ elevation in a coastal plain. The climate is tropical wet with summer 
rains, the average annual rainfall is $2200 \mathrm{~mm}$ and the mean annual temperature is $26{ }^{\circ} \mathrm{C}$ (Instituto Nacional de Estadística y Geografía [INEGI], 2001). The soil is Gleysol and the vegetation is mostly hydrophilic, dominated by Typha domingensis, E. palustris, Cyperus surinamensis, Cynodon plectostachyus, Echinochloa polystachya, L. hexandra, and Paspalum virgatum. Oil infrastructure includes nine pipelines from 6 to 20 inches in diameter, carrying crude oil, gas and ethane, is also a dam with residues of drilling an oil well. The spills of crude oil arrived at the farm via ruptured pipelines connecting the wells with storage batteries and La Venta Gas Processing Complex.

Oil spill and study areas: The oil spill occurred in 2006 and differently affected the farm depending on the distance to the contamination focus. Drilling was done with auger closed up to one meter deep in the soil. Four areas with different degrees of environmental impact were identified due to the chronic oil spill. Each area (A) consisted of a surface of $30 \mathrm{~m}^{2}(5 \times 6 \mathrm{~m})$. The area was cleared of native vegetation, and the soil was removed, crushed and homogenized. Soil was randomly collected from $10 \mathrm{~m}^{2}$ in each area leaving an effective border of $1.0 \mathrm{~m}$ width in order to evaluate the Total Petroleum Hydrocarbons in soil (TPHs) contents. The oil contents were determined using the modified soxhlet extraction method of EPA 3540B (United States Enviromental Protection Agency [USEPA], 1994). The samples were acidified with $\mathrm{HCl}$ to $\mathrm{pH} 2$ and then dried with $\mathrm{MgSO} 4$. Soxhlet extraction was undertaken for $8 \mathrm{~h}$ using dichloromethane of $99.5 \%$ purity (Merck ${ }^{\circledR}$ analysis). The solvent was evaporated and the dry weight of the extract was quantified in $\mathrm{mg} \mathrm{kg}^{-1}$ (gravimetry).

Experimental design and setup: The experiment was conducted as a $4 \times 2$ two factor factorial with four replicates: the first factor being TPHs content in soil (four levels: 912, 75560,91695 and $118879 \mathrm{mg} \mathrm{kg}^{-1}$ ), and the second one the plant type (two levels). In September 2014, $10 \mathrm{~cm}$ long fragments of stems with mature and differentiated buds of $L$. hexandra grass and E. palustris rhizomes collected in adjacent uncontaminated areas (300 of each species, equally distributed) were planted. Each area of $30 \mathrm{~m}^{2}$ was delimited with square wire-mesh fencing to prevent any grazing animals from invading the test sites. Neither fertilization nor watering was implemented during the growing period.

Foliar, soil and rhizosphere sampling: Nine months after the establishment of the experiment, four one square meter replicates were randomly established in each zone. Foliar biomass of both plant species was collected and dry matter production (DMP) was determined. Also, for each plant species, samples of bulk and rhizosphere soil (soil firmly adhered to roots) from individual plants were collected for assessments of assimilable sulfate $\left(\mathrm{SO}_{4}{ }^{-2}\right)$ and bacteria populations of subgroup Desulfovibrio.

Dry matter production: The aerial biomass (stems and leaves) of L. hexandra and E. palustris were washed with distilled water and were oven dried at $65{ }^{\circ} \mathrm{C}$ until constant weight determination.

Sulfate analysis: Bulk and rhizosphere soil samples from $L$. hexandra and E. palustris were dried, ground and sieved, and the assimilable $\mathrm{SO}_{4}^{-2}$ was determined with a buffer solution $\left(\mathrm{K}_{2} \mathrm{SO}_{2}, 2 \mathrm{~N}\right.$ glacial acetic acid and distilled $\left.\mathrm{H}_{2} \mathrm{O}\right)$ and a standard solution $\left[\mathrm{Ca}\left(\mathrm{H}_{2} \mathrm{PO}_{4}\right)_{2}\right.$. $\mathrm{H}_{2} \mathrm{O}, 2 \mathrm{~N}$ glacial acetic acid and distilled $\mathrm{H}_{2} \mathrm{O}$. Sulfate quantification was achieved by the turbidimetric method in a spectrophotometer at $670 \mathrm{~nm}$ (Etchevers, 1992).

Desulfovibrio population density: Bulk and rhizosphere soil of L. hexandra and $E$. palustris were stored at $4{ }^{\circ} \mathrm{C}$ for one week prior to analysis of the population of SRB (Desulfovibrio) which was evaluated in a specific culture medium (ML) under anaerobic conditions; ML medium was composed of the following $(\mathrm{g} / \mathrm{L})$ : Bacto agar ${ }^{\mathrm{TM}}$ 10, Bacto tryptone $\operatorname{agar}^{\mathrm{TM}}$ (tryptone 8 , peptone 2, dextrose 
15, agar 15 and bromocresol purple 0.04), $10 \mathrm{Na}_{2} \mathrm{SO}_{3}, \mathrm{FeSO}_{4}\left(\mathrm{NH}_{4}\right) 2 \mathrm{SO}_{4} \cdot 6 \mathrm{H}_{2} \mathrm{O}$ at $5 \%$, 10 Buffer solution (g/L): $\mathrm{MgCl} 0.811$ and $\mathrm{KH}_{2} \mathrm{PO}_{2}$ 0.34. The medium $\mathrm{pH}$ was adjusted $(7.6 \pm 0.1)$ previously and transferred into tubes with rubber lids perforated by metallic needles and autoclaved for $15 \mathrm{~min}$ at $120{ }^{\circ} \mathrm{C}$ (ASTM, 2009). The system was depressurized for oxygen removal through the needles, which were rapidly removed after autoclaving. The samples were inoculated using $1.0 \mathrm{~mL}$ each injected into $9 \mathrm{~mL}$ of the ML medium, through the metallic needles. After incubating in an anaerobic incubator for $48 \mathrm{~h}$ at $37{ }^{\circ} \mathrm{C}$, positive tubes for SRB showed black iron sulfide deposition (Fernández et al., 2006). To calculate the $\mathrm{CFU} / \mathrm{g}$ we used the most probable number with decimal dilutions and five tubes per dilution (Cochran, 1950).

Statistical analysis: The analysis of variance (ANOVA) of the factors (TPHs content and plant type) was calculated with respect to the parameters of the conducted study using the statistical program SAS version 8.01 (SAS, 2000). DMP, $\mathrm{SO}_{4}^{-2}$ and populations of Desulfovibrio in bulk and rhizosphere soil of $L$. hexan$d r a$ and E. palustris were subjected to one way ANOVA in order to test for significant differences between treatments $(p<0.05)$. Moreover, the pairwise correlation between DMP, TPHs, sulfate and Desulfovibrio in soil and rhizosphere in the contaminated treatments of both vegetal species was evaluated with Pearson's correlation-coefficient, using linear regression, for normally distributed variables with a statistical significance of $\mathrm{p}<0.05$.

\section{RESULTS}

Total Petroleun Hydrocarbons in soil (TPHs): The initial contents of TPHs ( $\left.\mathrm{mg} \mathrm{kg}^{-1}\right)$ in each area were A1: $912 \pm 230, \mathrm{~A} 2: 75560 \pm$ 13387, A3: $91695 \pm 19$ 467, and A4: 118789 \pm 18623 . The soils are strongly acidic $\left(\mathrm{pH} \mathrm{H}_{2} \mathrm{O}\right.$ from 4 to 4.6), clay loam texture, with 5.9, 9.5, 11.4 and $13.4 \%$ organic carbon, respectively.

Dry matter production: Contents of TPHs, plant type and their interaction were statistically significant. Dry matter production (DMP) of L. hexandra was significantly higher than of E. palustris independently of the TPHs content. Higher values for L. hexandra were reached with lower TPHs contents (A1 and A2), the DMP for E. palustris significantly increased with the higher TPHs contents (Fig. 1). For L. hexandra, a significant negative correlation was found between dry matter and both TPHs and sulfate contents in rhizosphere soil. By the contrary, DMP was significantly and positively correlated with Desulfovibrio populations in bulk soil. The dry matter of $E$. palustris was positive and significantly correlated with TPHs and sulfate contents in bulk soil, and negatively correlated with Desulfovibrio populations both in bulk and rhizosphere soil (Table 1).

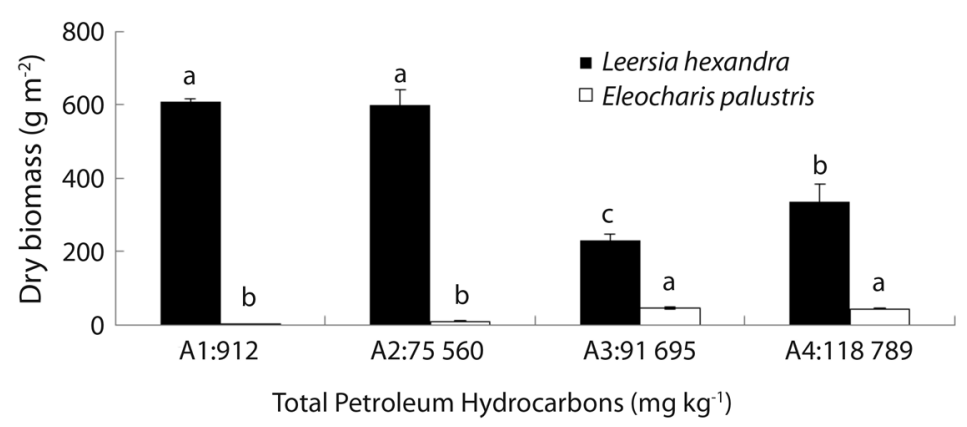

Fig. 1. Dry matter of Leersia hexandra and Eleocharis palustris after nine months growing in soil with different TPHs content. Each column represents the mean of four replications; bars indicate standard deviation. Means for each plant type followed by different letters are statistically significant at $\mathrm{p}<0.05$ as determined by Tukey's test. 
TABLE 1

Pairwise correlation coefficients and test for zero pairwise Pearson correlation of the corresponding variables at the ninth month of the experiment for Leersia hexandra and Eleocharis palustris in soils with TPHs contents

\begin{tabular}{|c|c|c|c|c|c|}
\hline & TPHs & $\mathrm{SO}_{4}^{-2}$-bulk soil & $\mathrm{SO}_{4}^{-2}$-rhizosphere & Dv - bulk soil & Dv - rhizosphere \\
\hline \multicolumn{6}{|l|}{ Leersia hexandra } \\
\hline${ }^{1} \mathrm{DMP}$ & $-0.690 *$ & -0.444 & $-0.623 *$ & $0.598^{*}$ & 0.244 \\
\hline${ }^{2} \mathrm{TPHs}$ & & $0.777 * *$ & $0.984 * *$ & $-0.987 * *$ & $-0.843 * *$ \\
\hline${ }^{3} \mathrm{SO}_{4}{ }^{-2}-$ bulk soil & & & $0.835 * *$ & $-0.740 * *$ & $-0.858 * *$ \\
\hline $\mathrm{SO}_{4}^{-2}$ - rhizosphere & & & & $-0.971 * *$ & $-0.887 * *$ \\
\hline${ }^{4}$ Dv - bulk soil & & & & & $0.881 * *$ \\
\hline \multicolumn{6}{|l|}{ Eleocharis palustris } \\
\hline DMP & $0.821 * *$ & $0.694 * *$ & 0.466 & $-0.727 * *$ & $-0.689 * *$ \\
\hline TPHs & & $0.908 * *$ & $0.698 * *$ & $-0.969 * *$ & $-0.948 * *$ \\
\hline $\mathrm{SO}_{4}^{-2}$ - bulk soil & & & $-0.824 * *$ & $-0.790 * *$ & -0.489 \\
\hline $\mathrm{SO}_{4}^{-2}$ - rhizosphere & & & & $-0.723 * *$ & $-0.732 * *$ \\
\hline Dv - bulk soil & & & & & $0.995 * *$ \\
\hline
\end{tabular}

${ }^{1}$ Dry matter production, ${ }^{2}$ Total Petroleum hydrocarbons, ${ }^{3}$ Sulfate, ${ }^{4}$ Desulfovibrio, $*$ Significant at $\mathrm{p}<0.05$ and $* *$ Significant at $\mathrm{p}<0.01$.

Sulfate contents: Contents of $\mathrm{SO}_{4}^{-2}$ in bulk and rhizosphere soil of L. hexandra and E. palustris were significantly different among contamination levels (Fig. 2). In general, sulfate contents in rhizosphere soil was significantly higher than in bulk soil with the exception of $L$. hexandra growing in the less contaminated area. There were no significant differences between plant types (Table 1). For L. hexandra, sulfate contents in bulk and rhizosphere soil were significantly and positively correlated between them and with TPHs. Also, sulfate contents were negative and significantly correlated with Desulfovibrio populations in bulk and rhizosphere soil (Table 1). For E. palustris, sulfates in bulk and rhizosphere soil were negative and significantly correlated between them, and with Desulfovibrio populations in bulk
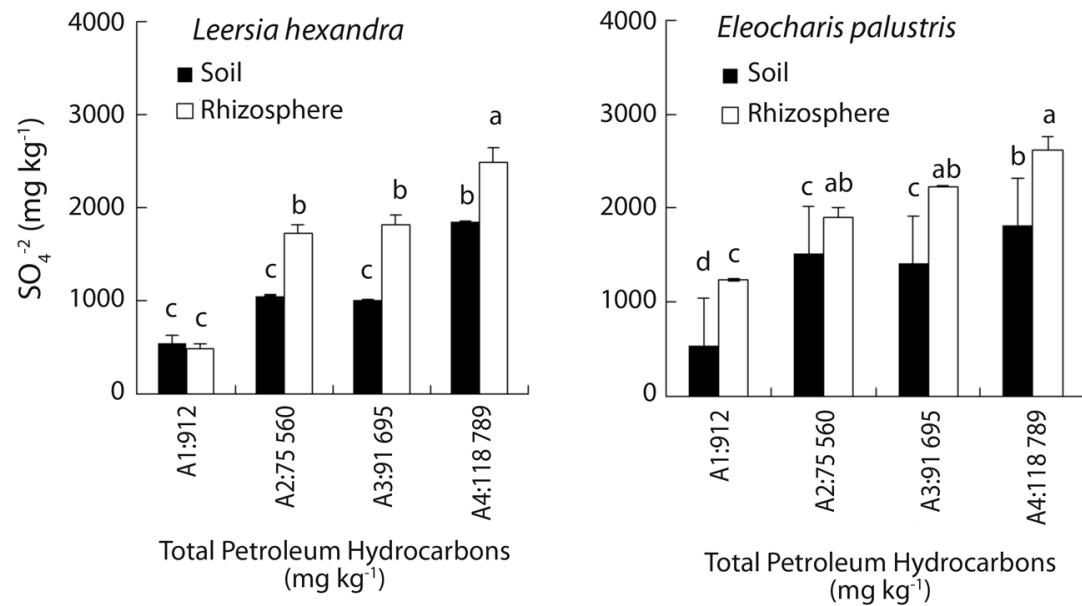

Total Petroleum Hydrocarbons $\left(\mathrm{mg} \mathrm{kg}^{-1}\right)$

Fig. 2. Sulfate in bulk and rhizosphere soil of Leersia hexandra and Eleocharis palustris after nine months growing in soil with different TPHs contents. Each column represents the mean of four replications; bars indicate standard deviation. Means not sharing letters are statistically different at $\mathrm{p}<0.05$ as determined by Tukey's test. 


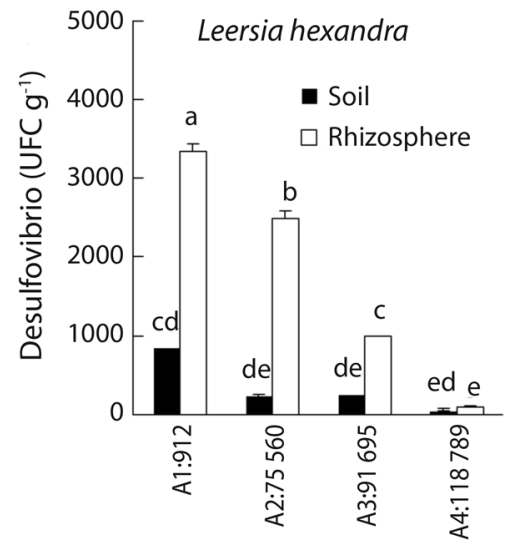

Total Petroleum Hydrocarbons $\left(\mathrm{mg} \mathrm{kg}^{-1}\right)$

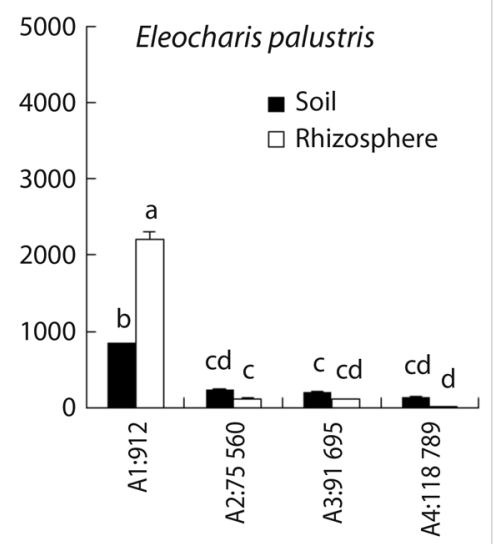

Total Petroleum Hydrocarbons $\left(\mathrm{mg} \mathrm{kg}^{-1}\right)$

Fig. 3. Desulfovibrio in bulk and rhizosphere soil of two plant species, after nine months growing in soil with different TPHs content. Each column represents the mean of four replications; bars indicate standard deviation. Means not sharing letters are statistically different at $\mathrm{p}<0.05$ as determined by Tukey's test.

soil. Sulfates and Desulfovibrio populations, both in rhizosphere soil, were also negatively and significantly correlated (Table 1).

Desulfovibrio population density: Desulfovibrio populations in $L$. hexandra were always significantly higher in rhizosphere than in bulk soil. For this plant higher Desulfovibrio amounts were obtained in the less contaminated soil, diminishing progressively with higher oil contents. In E. palustris the rhizosphere effect on Desulfovibrio populations was only significant with the lower oil contents, where rhizosphere populations were higher than in bulk soil. With higher oil contents Desulfovibrio populations diminished considerably, with no differences between bulk and rhizosphere soil (Fig. 3). Desulfovibrio populations in bulk and rhizosphere soil of both plants tested were negatively and significantly correlated with TPHs, and positively and significantly correlated between them (Table 1).

\section{DISCUSSION}

Different studies have shown the inhibitory effect of oil on plant growth (Merkl, Schultze-Kraft, \& Infante, 2004; Rivera-Cruz,
Trujillo-Narcía, Miranda, \& Maldonado, 2005; Hou, Liu, Zhang, Hu, \& Cao, 2016), although in some cases it is different. In this research, the DMP production of $L$. hexandra significantly decreased with higher TPHs contents. Similar inhibitory results were found by Rivera-Cruz \& Trujillo-Narcía (2004) in the grasses E. polystachya and $B$. mutica, in a Gleysol with TPHs of $79457 \mathrm{mg} \mathrm{kg}^{-1}$ who indicated that the DMP of both species decreased by 32 and 44.1 $\%$, respectively. They attributed such behavior to lower height, thin stems achieved by the grass and some runners falling on the soil and not being rooted enough to produce tillers, thus leaving gaps. Likewise found that Eleusine indica biomass decreased by $46.8 \%$ in soil with $5 \%$ oil (Merkl et al., 2005).

One explanation they describe is that the life cycle of this species is delayed in the presence of TPHs, because they affect the amount of plant growth regulators, hence suggesting that patterns of plant growth are affected by the oil contained in the soil. Classic studies (Plice, 1949; Baker, 1971) pointed out that some plants can increase their growth in soils with oil. In our research, the biomass production of E. palustris spikerush showed a direct proportional response to the increase of the oil in the soil, whereas the ratio was inversely related 
to the production of $L$. hexandra biomass. Oil inhibited the growth of this grass. The results of DMP in E. palustris shows a positive trend with the increase of the amount of oil in the soil. It resembles the effect of hormesis that occur in plants adapted to stressors by exposure to a pollutant during long periods of the life cycle (Calabrese, Baldwin, \& Holland, 1999). According to Vaziri et al. (2013) the higher production of dry vegetable matter can be effective because of the greater exploration of the radical system and also the radical exudates that improve the catabolic activity of the rhizospheric microorganisms. One type of adaptation of plants growing on oil-contaminated soils is the increase in quantity and thickness of the root, it covers a larger area of exploration. E. palustris has morphological and physiological characteristics that stimulate the adaptation and growth of the plant to unfavorable conditions (Hauser, 2006; Tilley \& John, 2012). It is a pioneer species that covers the clay soil very quickly as the water level decreases, and also under flood conditions, it is dominant in all serous stages. It is early seral because of the rapid rhizomatous growth in warm environments, both in soil with water table at $30 \mathrm{~cm}$ below the surface, also in flooded terrains. According Tilley \& John (2012) the elongation of the rhizome follows an almost linear trajectory to escape the competition of the same species. The same authors also mention that $E$. palustris has a dense root mass that extends more than $40 \mathrm{~cm}$ in the depth of the soil. It thrives in disturbed places. Species used for restoration of wetlands. It can fix atmospheric nitrogen and make it available to other plants in the wetland community (Tilley \& John, 2012). This set of vegetal attributes may be related to the increase of the vegetal biomass in soils contaminated with greater amounts of petroleum. Only when TPHs contents partially inhibited the growth of L. hexandra, it was that E. palustris increased.

There was a significant correlation between TPHs and sulfate contents both in bulk and rhizospheric soil. The presence of high amounts of sulfur in soils adjacent to the study area was reported by (Fernández et al., 2006), and the increases of sulfate in the study area may be due to the high content of sulfuric-containg organic molecules (sulfide, disulfide, mercaptan, thiophene, benzothiophene and dibenzotione derivatives of resins and asphaltenes) (Waiquer, 2004) contained in the oil spill, which could have been released through mineralization processes. The accumulation of $\mathrm{SO}_{4}^{-2}$ was stimulated in both rhizospheres evaluated in this research and this could be explained by the presence of the roots, introducing oxygen and inducing the establishment of chemoautotrophic bacteria which oxidize hydrogen sulfide $\left(\mathrm{H}_{2} \mathrm{~S}\right)$, elemental sulfur $\left(\mathrm{S}_{0}\right)$ and thiosulfate $\left(\mathrm{S}_{2} \mathrm{O}_{3}{ }^{-2}\right)$ in the soil (Lynch \& Hobbie, 1988). Also, could partially be explained by the mineralization of soil organic carbon and lysis of microorganisms. The effect of the TPHs content, plant type and interactions were significant for Desulfovibrio in rhizosphere soil, where populations of these bacteria were always higher in $L$. hexandra than in E. palustris. The type of plant had no effect on the bulk soil.

According to Alexander (1994) sulfate reducing bacteria in acidophilus anoxic environments saturated with $\mathrm{S}$, occur naturally in amounts between $10^{2}$ to $10^{4} \mathrm{CFU}$ per gram of soil. In our research the population subgroup Desulfovibrio fitted this range in bulk and rhizospheric soil of $L$. hexandra, while these bacteria populations in E. palustris were considerably lower (Fig. 3). In rhizosphere soil of L. hexandra, there was a significant increase in Desulfovibrio populations with regard to bulk soil, this rhizosphere effect has been reported to be favored by pastures (like $L$. hexandra) over other plant species, as noted by Badalucco \& Kuikman (2001) in Holcus lanatu, Anthoxanthum odoratum, Festuca rubra, and Festuca ovina. Sacaca, Iñiguez \& Roulet, (2009) reported an increase in populations and selectivity of sulfate reducing bacteria belonging to the subgroup Desulfobacter in roots of aquatic plants. In our study the rhizosphere of $L$. hexandra induced proliferation of Desulfovibrio to a greater extent than E. palustris. 
This response could be attributable to the type of fibrous root system, extensively characterizing $L$. hexandra. This root architecture has been linked to an increase in the availability of $\mathrm{SO}_{4}^{-2}$ in different pastures growing in anoxic environments (Aprill \& Sims, 1990), which is also a characteristic of our study area. The presence of Desulfovibrio in these environments is linked to its intervention in processes of nutritional sulfate assimilation. Madigan et al. (2015) noticed that Desulfovibrio sulfofidismutans promotes the reduction of sulfur compounds using an intermediate oxidation state, wherein one compound is oxidized and another is reduced, thus reducing thiosulfate $\left(\mathrm{S}_{2} \mathrm{O}_{3}{ }^{-2}\right)$, sulfite $\left(\mathrm{SO}_{3}{ }^{-2}\right)$ and sulfur $\left(\mathrm{S}_{0}\right)$.

Hence, an atom of sulfur thiosulfate is oxidized $\left(\mathrm{SO}_{4}^{-2}\right)$ and another is reduced (forming $\mathrm{H}_{2} \mathrm{~S}$ ). The small population densities of Desulfovibrio, in the soil and in the rhizosphere of L. hexandra and E. palustris, are of few importance in the elimination of petroleum in the soil, this explains why this bacterium uses a limited number of sources of C (Parés \& Juárez, 1997). This low spectrum of usable substrates is because the sulfate oxidation has low energy yield, therefore the energy that can be obtained from the oxidation of the substrate is small (Madigan et al., 2015; Parés \& Juárez, 1997). It is known that the rate of biodegradation of organic compounds under anaerobic conditions is lower than aerobic conditions caused by the lower amount of energy sources, consequently decreasing the multiplication of new generations of bacteria (Madigan et al., 2015; Parés \& Juárez, 1997; Santos, Carmo, Pases, Rosado, \& Peixoto, 2011), even the presence of sulphate in the soil and rhizosphere inhibited Desulfovibrio density in both plants (Table 1). The greater permanence of the oil in flooded soils may be precisely due to the decrease of the microbial activity, so that the persistence of the contaminant can last for decades. The reintroduction of the vegetation cover in a tropical wetland contaminated with petroleum and sulfate evidenced different effects in the growth and development of L. hexandra grass and in E. palustris spikerush. Desulfovibrio population's densities were higher in rhizospheres of both plant species but decreased in soils contaminated with petroleum and sulfate. E. palustris plant showed adaptation during the nine months of exposure to oil and sulfate, vegetative growth was not inhibited. We recommend the use of E. palustris for the decontamination of flooded soils contaminated with weathered oil and sulfate.

\section{ACKNOWLEDGMENTS}

MCRC thanks and acknowledges the financial support from Colegio de Postgraduados en Ciencias Agrícolas Campus Tabasco (project 40018). We acknowledge the valuable corrections of the reviewers.

\section{RESUMEN}

Reintroducción de cobertura vegetal en un humedal tropical contaminado con petróleo y sulfato: efecto de la rizosfera sobre poblaciones de Desulfovibrio. El humedal tropical mexicano es un sistema costero con capacidad para resistir la contaminación derivada de la industria extractiva y la transformación del petróleo crudo, debido a su alta biodiversidad de plantas y la presencia de bacterias rizosféricas reductoras de sulfato de plantas tolerantes al petróleo crudo. Se realizó un experimento en campo durante nueve meses para evaluar la adaptación de las plantas acuáticas Leersia hexandra y Eleocharis palustris reintroducidas en un humedal contaminado con 75560 a 118789 $\mathrm{mg} \mathrm{kg}^{-1}$ de petróleo intemperizado y también con sulfato, derivados de fugas de oleoductos y de emisiones gaseosas crónicas. Se evaluó el efecto del petróleo intemperizado y del sulfato en la producción de materia seca vegetal y en la densidad poblacional de la bacteria Desulfovibrio spp, aislada de la rizosfera y del rizoplano de ambas especies vegetales. Las medias de las variables tuvieron diferencias estadísticas ( $\mathrm{p}<0.05)$. El petróleo intemperizado inhibió la producción de materia seca de $L$. hexandra pero no de $E$. palustris; el efecto del petróleo en la densidad de Desulfovibrio fue negativo muy significativo en la rizosfera y en el rizoplano de ambas plantas. El sulfato redujo la materia seca de L. hexandra. La exposición de Desulfovibrio a sulfato redujo muy significativamente $(\mathrm{p}<0.01)$ su densidad en rizosfera y en rizoplano. Recomendamos el uso de $E$. palustris para la descontaminación de suelos inundables afectados con petróleo intemperizado y con sulfato.

Palabras clave: bacteria; Gleysol; Eleocharis; Leersia; petróleo intemperizado. 


\section{REFERENCES}

Alexander, M. (1994). Introducción a la Microbiología del Suelo (2a. reimp.). México: AGT Editor, S.A.

Aprill, W., \& Sims, R. C. (1990). Evaluation of the use of prairie grasses for stimulating polycyclic aromatic hydrocarbon treatment in soil. Chemosphere, 20(12), 253-265.

ASTM. (2009). D4412-84, Standard Test Methods for Sulfate-Reducing Bacteria in Water and WaterFormed Deposits. West Conshohocken, PA: ASTM International.

Atlas, R. M., \& Bartha, R. (2002). Ecología Microbiana y Microbiología Ambiental (4a. ed.) España: Pearson Educación.

Babu, P. G., Subramanyam, P., Sreenivasulu, B., \& Paramageetham, Ch. (2014). Isolation and identification of sulfate reducing bacterial strains indigenous to sulphur rich barite mines. International Journal of Current Microbiology and Applied Sciences, 3(7), 788-793.

Badalucco, L., \& Kuikman, J. P. (2001). Mineralization and Immobilization in the Rhizosphere. In R. Pinto, Z. Varanini, \& P. Nannipieri (Eds.), The Rhizosphere: Biochemistry and Organic Substances at the SoilPlant Interface (pp. 159-196). New York: CRC Press.

Baker, J. M. (1971). Growth stimulation following oil pollution. In E. B. Cowell (Ed.), The Ecological Effects of Oil Pollution on Littoral Communities (pp. 72-77). London: The Institute of Petroleum.

Basumatary, B., Bordoloi, S., \& Sarma, P. H. (2012). Crude oil-contaminated soil phytoremediation by using Cyperus brevifolius (Rottb.) Hassk. Water Air and Soil Pollution, 223(6), 3373-3383.

Calabrese, E. J., Baldwin, L. A., \& Holland, C. D. (1999). Hormesis: A highly generalizable and reproducible phenomenon with important implications for risk assessment. Risk Analysis, 19(2), 261-281.

Cochran, S. W. G. (1950). Estimation of bacterial densities by means of the "most probable number". Biometrics, 6(2), 105-116.

CONABIO. (2009). Manglares de México: Extensión y distribución. Comisión Nacional para el Conocimiento y Uso de la Biodiversidad. México: CONABIO.

Dzantor, E. K. (2007). Phytoremediation: the state of rhizosphere 'engineering' for accelerated rhizodegradation of xenobiotic contaminants. Journal of Chemical Technology and Biotechnology, 82(3), 228-232.

Erickson, L. E., Davis, L. C., \& Narayanan, N. (1995). Bioenergetics and bioremediation of contaminated soil. Thermochimica Acta, 250(2), 353-358.
Etchevers, B. J. D. (1992). Manual de métodos para análisis de suelos, plantas agua y fertilizantes. Análisis rutinarios en estudios y programas de fertilidad. Montecillos. México: Laboratorio de Fertilidad, Centro de Edafología. Colegio de Postgraduados en Ciencias Agrícolas.

Fernández, L. J. C., Rojas, A. N. G., \& Roldán, C. T. G. (2006). Manual de técnicas de análisis de suelos aplicadas a la remediación de sitios contaminados. México: Instituto Mexicano del Petróleo, Secretaría de Medio Ambiente y Recursos Naturales, Instituto Nacional de Ecología.

García, C., Moreno, D. A., Ballester, A., Blázquez, M. L., \& González, F. (2001). Bioremediation of an industrial acid mine water by metal-tolerant sulfate-reducing bacteria. Minerals Engineering, 14(9), 997-1008.

Hansen, T. A. (1994). Metabolism of sulfate-reducing prokaryotes. Anton Leeuw Int JG, 66(1-3), 165-185.

Hauser, A. S. (2006). Eleocharis palustris. In Fire Effects Information System. Accessed 22.07.2017. S. Department of Agriculture, Forest Service, Rocky Mountain Research Station, Fire Sciences Laboratory (Producer). http://www.fs.fed.us/database/feis

Hou, Y., Liu, X., Zhang, X., Hu, X., \& Cao, L. (2016). Rhizosphere phytoremediation with Cyperus rotundus for diesel-contaminated wetlands. Water Air and Soil Pollution, 227(1), 26.

Hurst, C. J. (2002). An introduction to viral taxonomy and the proposal of Akamara, a potential domain for the genomic a cellular agents. In C. J. Hurst (Ed.), Viral Ecology (pp. 41-62). USA, San Diego: Academic Press.

Instituto Nacional de Estadística y Geología [INEGI]. (2001). Síntesis de Información Geográfica del Estado de Tabasco (1a. ed.). México: Instituto Nacional de Estadística y Geografía.

Liamleam, W., \& Annachhatre, A. P. (2007). Electron donors for biological sulfate reduction. Biotechnology Advances, 25(5), 452-463.

Lynch, J. M., \& Hobbie, J. E. (1988). Micro-organisms in Action: Concepts and Applications in Microbial Ecology. Oxford: Blackwell Scientific Publications.

Madigan, M. T., Martinko, J. M., Bender, K. S., Buckley, D. H., \& Stahl, D. A. (2015). Brock. Biología de los microorganismos (14a. edición). España: Pearson Educación.

Martí, M. C., Camejo, D., Fernández-García, N., RellánÁlvarez, R., Marques, S., Sevilla, F., \& Jiménez, A. (2009). Effect of oil refinery sludges on the growth and antioxidant system of alfalfa plants. Journal of Hazardous Materials, 171(1-3), 879-885. 
Merkl, N., Schultze-Kraft, R., \& Infante, C. (2004). Phytoremediation in the tropics-The effect of crude oil on the growth of tropical plants. Bioremediation Journal, 8(3-4), 177-184.

Merkl, R. N., Schultze-Kraft, R., \& Infante, C. (2005). Assessment of tropical grasses and legumes for phytoremediation of petroleum - contaminated soils. Water Air and Soil Pollution, 165(1-4), 195-209.

Muratova, A. Y., Dmitrieva, T. V., Panchenko, L. V., \& Turkovskaya, O. V. (2008). Phytoremediation of oilsludge-contaminated soil. International Journal of Phytoremediation, 10(6), 486-502.

Parés, I. F. R., \& Juárez, G. A. (1997). Bioquímica de los microorganismos. España: Editorial Reverté, S.A.

Plice, M. J. (1949). Some effects of crude petroleum on soil fertility. Soil Science Society of America, 13(C), 413-416.

Rivera-Cruz, M. C. (2011). Bacterias y hongos en suelos contaminados con petróleo crudo en Tabasco. In M. A. Gamboa, \& R. H. Rojas (Eds.), Recursos genéticos microbianos en la zona del Golfo-Sureste de México (pp. 77-96). México: Subsistema Nacional de Recursos Genéricos Microbianos (Subnargem), SAGARPA.

Rivera-Cruz, M. C., Trujillo-Narcía, A., Miranda de la, C. M. A., \& Maldonado, C. E. (2005). Evaluación toxicológica de suelos contaminados con petróleo nuevo e intemperizado mediante ensayos con leguminosas. Interciencia, 30(6), 326-331.

Rivera-Cruz, M. C., Maldonado-Chávez, E., \& TrujilloNarcía, A. (2012). Effects of crude oil on the growth of Brachiaria mutica and Leucaena leucocephala and on soil and plant macronutrients. Tropical and Subtropical Agroecosystems, 15(SUP 2), S30-S39.
Rivera-Cruz, M. C., Trujillo-Narcía, A., Trujillo-Rivera, E. A., Arias-Trinidad, A., \& Mendoza-López, M. R. (2016). Natural attenuation of weathered oil using aquatic plants in a farm in southeast Mexico. International Journal of Phytoremediation, 18(9), 877-884.

Sacaca, C. S., Iñiguez, R. V., \& Roulet, M. (2009). Diversidad y distribución de bacterias sulfato reductoras en sedimentos de lagunas de la cuenca Milluni contaminada por desechos mineros. Biofarbo, 17(2), 39-50.

Santos, F. H., Carmo, L. F., Paes, S. E. J., Rosado, S. A., \& Peixoto, S. R. (2011). Bioremediation of mangroves impacted by petroleum. Water Air and Soil Pollution, 216(1-4), 329-350.

SAS Institute Inc. (2000). The SAS System for Windows Release 8.01. [Computer software]. NC: SAS Institute Inc.

Tilley, D., \& John, L. (2012). Plant Guide for common spikerush (Eleocharis palustris). USDA-Natural Resources Conservation Service, Aberdeen Plant Materials Center. Aberdeen, Idaho 83210. Recovered on 22.07.2017 from: https://www.nrcs.usda.gov/ Internet/FSE PLANTMATERIALS/publications/ idpmcfs11627.pdf

USEPA. (1994). Test methods for evaluating solid and hazardous waste. Washington, DC.

Vaziri, A., Panahpour, E., \& Mirzaee-Beni, M. H. (2013). Phytoremediation, a method for treatment of petroleum hydrocarbons contaminated soils. International Journal of Farming and Allied Sciences, 2(21), 909-913.

Wauquier, J. P. (2004). El refino de petróleo: Petróleo crudo, productos petroliferos y Esquemas de Fabricación. México: Ediciones Díaz de Santos. 